\title{
Water quality threatens Polish agriculture
}

Following an unusually severe winter and dry spring, Poland faces a short-fall in the harvest, a situation in which Party Leader Edward Gierek, meeting agricultural 'activists' earlier this month, could only advise them to "take a close look at every field and harvest as much grain as possible. We must not run round looking for possible places where grain can be bought. Firstly, the money is not there, and secondly, we cannot buy grain anywhere'.

Although attributable in the short term to exceptional climatic conditions, this short-fall is a symptom of one of the major problems bedevilling the Polish economy, a chronic lack of water. Not only do many parts of the country have an overall deficit of water, even where there is abundent rainfall, there is unsufficient reservoir capacity to store it. In all, Poland's existing 140 reservoirs can hold only 2,800 million $\mathrm{m}^{3}$ water, some $5 \%$ of the mean annual flow of the rivers (for comparison, Bulgaria stores $15 \%$, Czechoslovakia $12 \%$ and the Soviet Union more than $14 \%$ ).

Although the new Vistula Programme, formally inaugurated on 18 June 1978, is designed to remedy this situation to give a storage capacity for the Vistula of approximately 6,000 million $\mathrm{m}^{3}$, in addition to modernizing the river's transport facilities and building hydroelectric stations. However, provision of water is not sufficient. The Vistula is now so polluted that for much of its length, the water is not even up to the 'second class' of cleanness required for agriculture. A spokesman for the Programme, told Nature that "the main purpose of the Programme is to provide the nation with

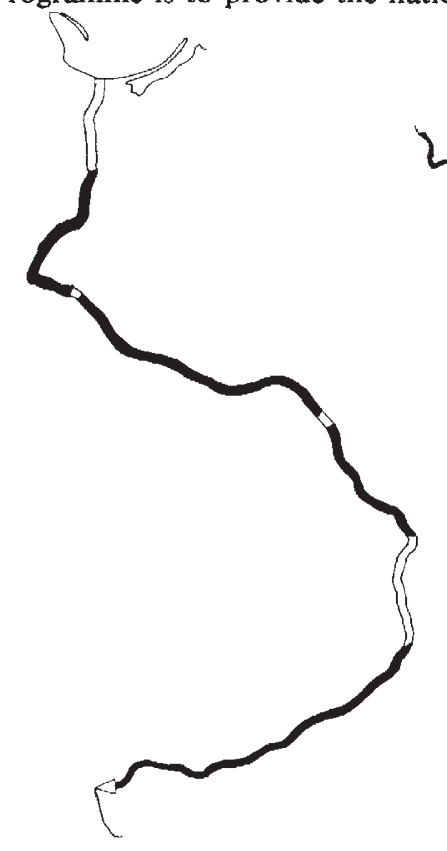

pure water. All the other aspects, transport, hydroelectricity etc, could be replaced by some other means. But without pure water there is nothing we can do."

Like all major technological undertakings in Poland, the Vistula Programme draws heavily on scientific potential throughout the country. Virtually all major Universities and Polytechnics are involved, especially Warsaw, Krakow and Wroclaw. Coordination is the responsibility of the Academy of Sciences.

Although work on the Vistula Programme is not due to start until 1981, the extreme urgency of the situation has led those involved to anticipate the official inauguration. A few administrators have already moved into the half-built office block in the Warsaw suburbs assigned to the Programme, while on the river itself preliminary dredging operations are already in operation. Yet even at this early stage, the engineering operations seem likely to be held up by environmental problems.

Plans for the river include floodwalls which will enclose the present channel and the water-meadows susceptible to flooding; dams will then be built between these floodwalls to create reservoirs with a minimum depth of $2 \mathrm{~m}$. The Institute of Ecology of the Academy of Sciences has decided, however, that no dams should be built until the water in that area is up to second class standard, a demand of unparalleled severity.

Cleaning up the Vistula to an extent where largescale engineering operations can commence will involve a considerable number of interests. In addition to the

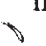

routine problems of industrial outfall and domestic sewage, there is heavy mineral pollution from the mining and industrial belt of Silesia, to say nothing of the Nowa Huta Steelworks near Krakow, where the ecological price of the annual steel output of 7 million tonnes is an emission of 100,000 tonnes of dust and some 70,000 tonnes of $\mathrm{SO}_{2}$.

Many ecologists concerned with the Vistula Programme see this indirect pollution via soil and air as a greater problem than that of wastes discharged into the water, which can, at least in principle, be dealt with by improved sewage, recycling, oil-trap and purification systems. The Academy's Environmental Engineering Institute (situated appropriately, at Zabrze in Silesia), is working on a new electric filter, now at the pilot model stage. Filters and precipitators have in fact installed on all new furnaces at Nowa Huta since the mid-1960s; of them, Professor Roman Andrzeiewski, of the Environmental Engineering Institutes Krakow office simply observed "The filters would be fine if they had an efficiency of $90 \%$ ". What is really needed, he added is " a technology without dust and without gas!"

Until that utopian situation is achieved, the Institute of Ecology is trying to work out some ecological solution to the pollution problem. In Silesia, valuable data have already been collected on the uptake of minerals. Although it is far too early to propose a general strategy, some partial solutions have been suggested. Zinc pollution, for example, can be remedied by planting birch trees, which can apparently accumulate zinc without harm. Similar methods, say the researchers, can also be applied to agricultural run-offs.

To avoid eutrophication of the future reservoirs, they propose filter zones of live ecosystems on either side of the river. Alder woods are particularly valuable, as too is grass-land, which can profitably be used for grazing. Preliminary studies on the disposal of agricultural chemicals by such filters is going forward in the Mazurian lake disrict. Not only the absorption by flora is being investigated, but also the uptake and "export" of the chemicals via the small fauna.

But, faced with a pressing lack of water, as highlighted by the current harvest estimates, will the planners be prepared to wait? It is not, of course, the specific task of the Institute of Ecology to hold them off - but the consensus of opinion seemed optimistic. "We asked the engineers about this last year"', said one ecologist, and they said that they would never put a dam where it would make the water quite dead!" "We fell sure that the planners will do what we suggest," said another, "they are actually trying to improve their contacts with us".

Vera Rich 